\title{
Livestock Feed Production from Sago Solid Waste by Pretreatment and Anaerobic Fermentation Process
}

\author{
Siswo Sumardiono ${ }^{1, *}$, Aditya Dwi W N ${ }^{1}$, Farel Rahman $\mathrm{A}^{1}$, and Isti Pudjihastuti ${ }^{2}$ \\ ${ }^{1}$ Department of Chemical Engineering, Faculty of Engineering, Diponegoro University, Jl.Prof. Soedarto, SH, Tembalang, Semarang, \\ Indonesia 50275 \\ ${ }^{2}$ DIII Study Program, School of Vocation, Diponegoro University, Jl.Prof. Soedarto, SH, Tembalang, Semarang, Indonesia 50275
}

\begin{abstract}
Food needs in Indonesia is increasing, including beef. Today, Indonesia has problem to do selfsufficiency in beef. The cause of the problem is the quality of local beef is still lower compared with imported beef due to the quality of livestock feed consumed. To increase the quality of livestock is through pretreatment and fermentation. Source of livestock feed that processed is solid sago waste (Arenga microcarpa), because in Indonesia that is relatively abundant and not used optimally. Chemical pretreatment process for delignification is by using $\mathrm{NaOH}$ solution. The purposes of this research are to study $\mathrm{NaOH}$ pretreatment, the addition of Trichoderma $s p$, and fermentation time to improve the quality of sago solid waste as livestock feed through anaerobic fermentation. The variables used are addition or without addition (4\% $\mathrm{NaOH}$ solution and Trichoderma sp 1\%w) and fermentation time (7, 14 and 21 days), with the response of crude fiber and protein. The result of this research shows that the pretreatment with soaking of $\mathrm{NaOH}$ solution, addition of Trichoderma $s p$ and 14 days of fermentation was more effective to improve the quality of solid sago waste with decrease of crude fiber from $33.37 \%$ to $17.36 \%$ and increase of crude protein from $4.00 \%$ to $7.96 \%$.
\end{abstract}

\section{Introduction}

The Government of Indonesia has made a solution to continue to reduce the famine by making food selfsufficiency policy. Beef is one example of the food. Beef is a kind of food that has multiple roles, both in terms of food security and economy. The increase in beef prices is currently the result of an imbalance between production quotas and the level of public demand for beef [1]. The consequence is that Indonesia must import beef. Based on statistical data on import and export volume of beef during 1996-2015 [2], the import volume of beef in Indonesia tends to increase every year with the highest number obtained in 2014 of 246,000 tons. The data shows that Indonesia is still can't to be selfsufficient in beef. The imported beef in Indonesia comes from the United States has a smooth and soft texture, contains high protein and beneficial to the human immune. This meat also has fat (marbling), as other premium beef meat, such Angus beef. The quality of USA beef is different when compared to the quality of local beef because of differences in the livestock feed [3].

Indonesia's conventional livestock feed products are declining due to weather conditions and fluctuations in price. This reason is causing for seeking alternative sources, environmentally friendly, economically acceptable, and socially acceptable non-conventional feed sources [4]. The livestock feed should also be able to become a mainstay feed in the long term. Potential and useful alternative livestock feed and also available throughout the year are generally from agricultural processing industries, for example, in the production of sago flour [5]. Sago plants (Arenga Microcarpa) grow in damp tropical regions. Currently, the use of sago only focuses on the starch contained in it [6]. The processing of sago flour is usually conducted near water sources such as rivers or creeks edge [7]. The process of sago flour processing in the palm sugar industry in Daleman village, Klaten regency, Central Java produces an average of 200 tons / year of sago flour with 659 tons / year or 2.19 tons / day [8].

Solid sago waste contains lignocellulose rich in cellulose that can be used optimally as a carbon source. The crude protein content of the sago waste is very low, i.e. $2.63 \%$, while the crude fiber content is $15.90 \%$ [9]. Sanchez [10] states that Cellulose and hemicellulose are also substances of plant tissue composed of different sugars. Cellulose is the main material that encloses the plant skeleton resulting from the process of photosynthesis of plants. This compound is not soluble in ordinary solvents and comprises a plurality of $\beta$-Dglucopyranose units connected via $\beta-1-4$ bonds to form straight and long chains reinforced by a cross-linked hydrogen bond providing a crystalline structure and arranged in a micro fibril. Hemicellulose is the second largest polysaccharide after cellulose. Hemicellulose is a complex polymer consisting of a mixture of different

Corresponding author: siswo.sumardiono@che.undip.ac.id 
monosaccharide polymers in which the constituent sugars are grouped in the form of hexoses (glucose, mannose, and galactose), pentose (silose, arabinopiranosa, arabinofuranosa), hexuronic acid (glucoronate, methylgucoromate, galactoromat), deoxyhexose (rammosa, fucosa) [11].

Lignin is an anti-nutrient for livestock that interfered with livestock digestion and decrease the nutritional value of animal feed ingredients [12]. Lignin is an undigested component, affecting the digestibility of crude fiber. This compound is an aromatic polymer of phenylpropanoid produced from synthesis of coniferyl, synaphyl, p-coumaryl alcohol. Lignin is highly resistant to any chemical degradation including enzymatic. Bases pretreatment usually use basic solutions such as $\mathrm{NaOH}$, $\mathrm{Ca}(\mathrm{OH}) 2$ (limestone) or ammonia to remove lignin and parts of hemicellulose, so this process can efficiently increase cellulosic enzyme capability [13]. Generally this pretreatment is conducted under low temperature conditions with long time and high base concentrations [14]. The advantage of using a base as a lignocellulose pretreatment is the presence of lignin destruction wherein lignin inhibits the action of the enzyme during the anaerobic process [15]. Alkali can damage ester bonds between lignin and xylem [16].

Fermentation is one of the ways to improve the quality of the material where in the process there is an overhaul of hard structures physically, chemically and biologically so that the material from complex structures becomes simple, thereby making the digestibility more efficient [17]. According to Oseni and Ekperigin [18], Fermentation of plant waste not only increases the contents of protein, fat or crude fiber, but also increases the content of essential minerals that can be useful to the body's metabolism. The purposes of this research are to study $\mathrm{NaOH}$ pretreatment, the addition of Trichoderma $\mathrm{sp}$ and fermentation time to improve the quality of solid sago waste as livestock feed through anaerobic fermentation.

\section{Materials and Method}

\subsection{Materials}

The material used in this study is solid sago waste from Jepara District (Central Java), Trichoderma sp from Pradipta Paramita Solo, molasses from Ungaran, $\mathrm{NaOH}$, aquadest, and acetic acid.

\subsection{Preparation Stage}

At this stage, the sago palm waste raw material is collected from sago palm processing industry in Plajan village, Jepara District, Central Java Province. Trichoderma sp was purchased from Pradipta Paramita Solo, molasses from Ungaran, while $\mathrm{NaOH}$ and acetic acid from the Indrasari chemical store. After that, preparation is conducted by sieving the solid sago waste and each variable is measured 50 grams.

\subsection{Operation Stage}

Solid sago waste was soaked with $4 \% \mathrm{w} \mathrm{NaOH}$ solution for 24 hours or heated with $4 \% \mathrm{w} \mathrm{NaOH}$ solution at $60 \mathrm{OC}$ for an hour. The pretreatment substrate is reduced to a $\mathrm{pH}$ of 5-6 with acetic acid and then fermented for 7, 14 and 21 days with Trichoderma sp and molasses. Fermentation process in this study conducted anaerobically.

\subsection{Result Analysis Stage}

The analysis was conducted graphically based on the phenomenon for the effect of the independent variables on the contents of crude fiber and crude protein.

\section{Results and Discussion}

\subsection{Effect of pretreatment type on Crude Fiber and Crude Protein Content}

Figure 1 and 2 shows the correlation of the pretreatment of $\mathrm{NaOH}$ and the crude fiber content of the feed material derived from the solid sago waste. In Figure 1, the solid sago waste variables without the addition of Trichoderma sp on the day 7 samples without pretreatment, heating pretreatment, and soaking pretreatment resulted in crude fiber content of 33.04\%; $27.50 \%$ and $22.03 \%$, respectively, on the day 14 samples without pretreatment, heating pretreatment, and soaking pretreatment resulted in crude fiber content of $33.01 \%$; $27.49 \%$ and $22.63 \%$, respectively, on the day 21 samples without pretreatment, heating pretreatment, and soaking pretreatment resulting in crude fiber content respectively $33.87 \% ; 27.98 \%$ and $23.00 \%$ respectively. In Figure 2, the solid sago waste variables with the addition of Trichoderma sp on the day 7 samples without pretreatment, heating pretreatment, and soaking pretreatment resulted in crude fiber content of $30.00 \%$; $27.01 \%$ and $21.79 \%$, respectively, on the day 14 samples without pretreatment, pretreatment heating and soaking pretreatment resulted in crude fiber content 25.18\%; $21.71 \%$ and $17.37 \%$, respectively, on the day 21 samples without pretreatment, heating pretreatment, and soaking pretreatment resulted in crude fiber content of $27.62 \%$; $24.53 \%$, and $19.11 \%$, respectively.

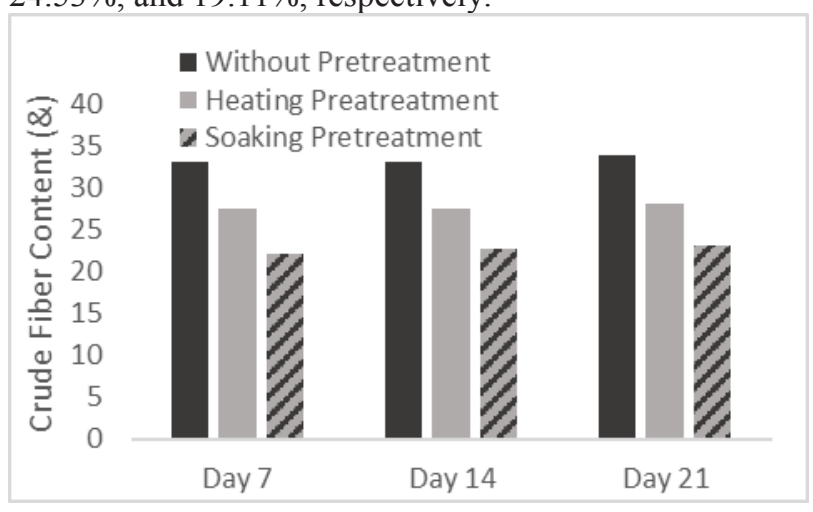

Fig. 1. Correlation of $\mathrm{NaOH}$ Pretreatment vs. Crude Fiber Content in Variables without Addition of Trichoderma sp. 


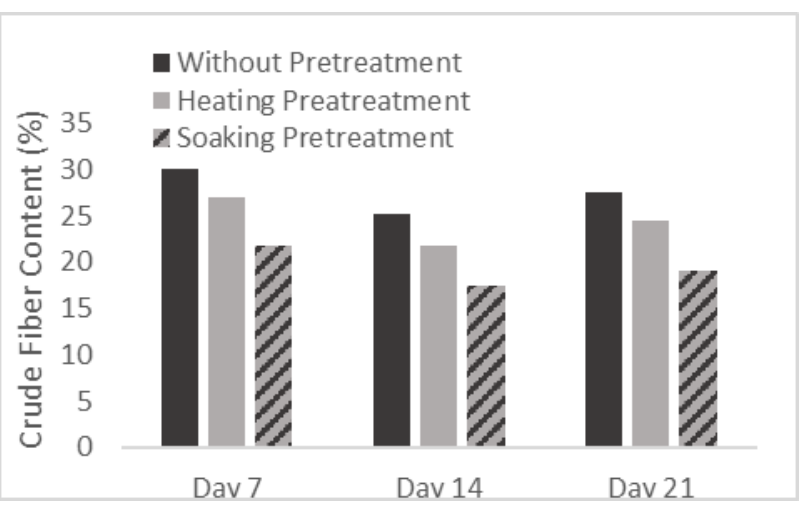

Fig. 2. Correlation of $\mathrm{NaOH}$ Pretreatment vs. Crude Fiber Content in Variables with Addition of Trichoderma sp.

From both figures it can be seen that the type of soaking pretreatment is more effective to decrease the crude fiber content in solid sago waste followed by heating pretreatment and without pretreatment. Choosing the right pretreatment method is very important because it determines which hydrolysis and fermentation methods will be used later [19]. The uses of strong base solution in this study aims to make the solid sago waste can undergo a delignification process before going into the fermentation process. Delignification of solid sago waste aims to damage the structure of lignin and a part of hemicellulose and also swelling of cellulose structures [20]. Saponification of ester bonds between lignin and hemicellulose residues makes cellulose more open and easier to interact with enzymes, and can decrease the degree of polymerization and crystallinity of cellulose structures [21]. This causes the crude fiber content that has passed the pretreatment stage to be lower than its original level.

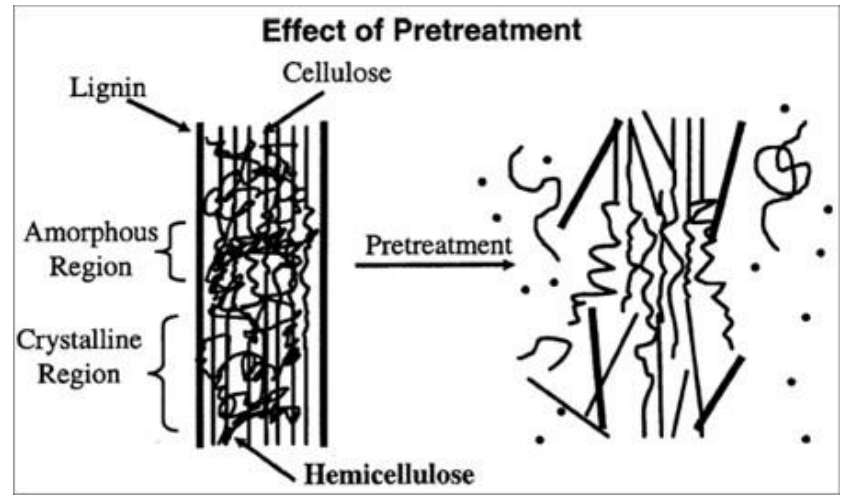

Fig. 3. Schematic process of destruction of lignin structure [22].

Compared with acid pretreatment, the base pretreatment method is more effective as lignin solubilization as presented in Figure 3. Base pretreatment methods in lignocellulose biomass processing are commonly use sodium, potassium, calcium, and ammonium hydroxide. The uses of a base solution cause changes in the structure of lignin by degrading the ester and glycoside side chain. The uses of base solution also cause partial decrystallization of cellulose, partial solubility of hemicellulose and resulting in enlarged cellulose. This process is carried out by soaking the biomass in an alkaline solution at a predetermined temperature and time. The loosened lignin binds to the $\mathrm{Na}+$ ion to form soluble sodium phenolate. Dissolved lignin is characterized by dark color in the solution (black liquor) [23,24]. The neutralization stage needs to be conducted before entering the enzymatic hydrolysis stage to remove lignin and inhibitor substances (eg salts, phenolic acids, and aldehydes) [25]. Pretreatment can increase lignocellulose digestibility in feedstuffs inhibited by several factors, such as: lignin content, cellulose crystallinity, polymerization degree, pore volume, acetyl group bound to hemicellulose, surface area and biomass particle size [26]. The factors that affecting the digestibility of feeds are contents of chemical, protein, fat presentations, fiber and minerals [27].

Figure 4 and 5 shows the correlation of the $\mathrm{NaOH}$ pretreatment type and the crude protein content of the feed material derived from the solid sago waste. In Figure 4, the solid sago waste variables without the addition of Trichoderma sp on the day 7 samples without pretreatment, heating pretreatment, and soaking pretreatment resulted in crude protein content of $3.96 \%$; $3.12 \%$ and $4.05 \%$, respectively, on the day 14 samples without pretreatment, heating pretreatment, and soaking pretreatment yielded crude protein content of $4.04 \%$; $3.18 \%$, and $4.06 \%$, respectively, on the day 21 samples without pretreatment, heating pretreatment, and soaking pretreatment yielded consecutive crude protein content $4.06 \% ; 3.24 \%$ and $4.11 \%$, respectively. In Figure 5, the solid sago waste variables with the addition of Trichoderma sp on the day 7 samples without pretreatment, heating pretreatment, and soaking pretreatment resulted in crude protein content of $2.80 \%$; $3.38 \%$ and $3.54 \%$, respectively, on the day 14 samples without pretreatment, heating pretreatment and soaking pretreatment resulted in crude protein content of $4.06 \%$; $5.99 \%$ and $7.96 \%$, respectively, on the day 21 samples without pretreatment, heating pretreatment, and soaking pretreatment resulted in crude protein content of $4.28 \%$; $6.14 \%$ and $8.07 \%$, respectively.

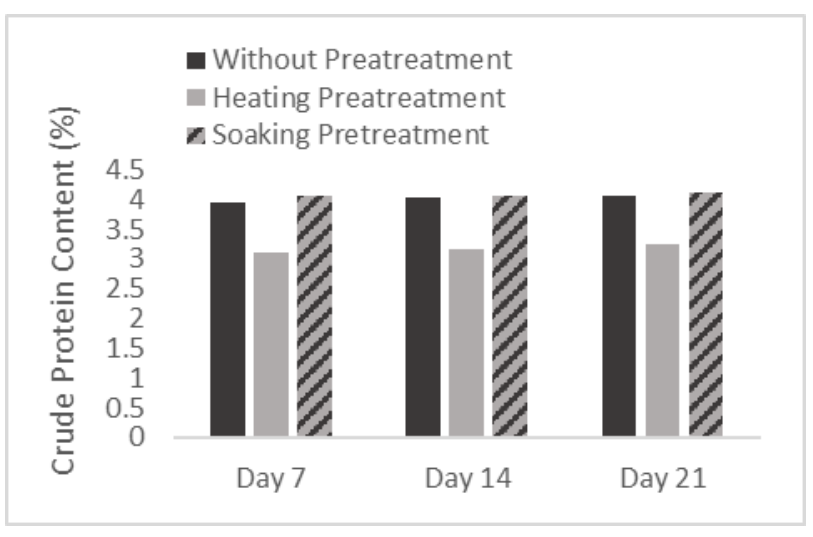

Fig. 4. Correlation of $\mathrm{NaOH}$ Pretreatment vs. Crude Protein Content in Variables Without Addition of Trichoderma sp. 


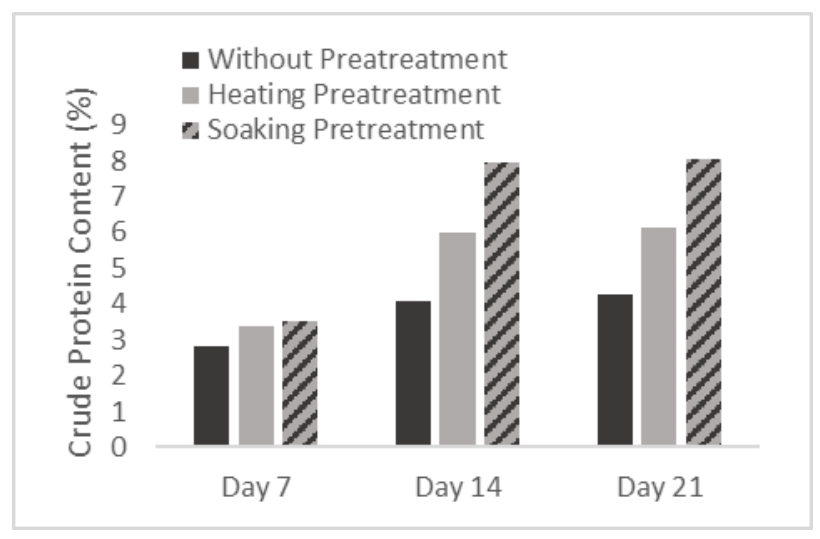

Fig. 5. Correlation of $\mathrm{NaOH}$ Pretreatment vs. Crude Protein Content in Variables with Addition of Trichoderma sp.

From both figures it can be seen that soaking pretreatment is best way to help raise the crude protein content in the solid sago waste followed by heating pretreatment and without pretreatment. Delignification of solid sago waste aims to damage the structure of lignin and swelling of cellulose structures [20]. According to Saparianti [28], lignin which is a substance of lignocellulose which is a component of crude fiber will prevent enzyme penetration into substrate. In the variable solid sago waste with the addition of Trichoderma sp, the presence of delignification can help the work of protease enzymes which are one of the enzymes that produced by Trichoderma $\mathrm{sp}$ to form protein compounds [29]. Solid sago waste that not added Trichoderma $\mathrm{sp}$ and without pretreatment procedure tends not to affect the crude protein content. In the variable with the pretreatment of heating at $60^{\circ} \mathrm{C}$ without Trichoderma sp there was a decrease in the crude protein content due to the nature of the protein having denaturation at 50 to $80{ }^{\circ} \mathrm{C}$. Each temperature increase of $10{ }^{\circ} \mathrm{C}$, protein denaturation rate increased to 600 fold [30]. The hydrogen bonds and hydrophobic interactions of non-polar ions of proteins can be damaged by heat.

According to Ophar [30] the kinetic energy that increase due to high temperatures can cause protein molecules to move or vibrate faster, thus breaking the bonds of the molecule. In addition, heat energy will lead to disconnection of non-covalent interactions that exist in the natural structure of the protein but do not break its covalent bond in the form of peptide bonds. Increased the content of crude protein in livestock feed consumed by livestock are good for livestock in terms of nutritional fulfillment. The quality of livestock feed depends on the composition of the nutrients contained therein mainly against dry matter, crude protein, crude fat, crude fiber and feed grade digestibility [31].

\subsection{Effect of the addition of Trichoderma sp on Crude Fiber and Crude Protein Content}

Figure 6, 7, and 8 shows the correlation of the effect of the addition of Trichoderma sp to the crude fiber content of the solid sago waste. Figure 6 shows the correlation of the effect of the addition of Trichoderma sp vs. crude fiber content to the solid sago waste variable without pretreatment. Figure 7 shows the correlation of the effect of the addition of Trichoderma sp vs. crude fiber content on the variable of solid sago waste with heating pretreatment. Figure 8 shows the correlation of the effect of the addition of Trichoderma sp vs. the crude fiber content to the solid sago waste variable with soaking pretreatment. In figure 6 , the solid sago waste without pretreatment (without the addition of Trichoderma $\mathrm{sp}$ and with the addition of Trichoderma $\mathrm{sp}$ ) resulted in crude fiber content: on the day 7 samples: $33.04 \%$ and $30.00 \%$, on the day 14 samples: $33.01 \%$ and $32.52 \%$, on the day 21 samples: $33.87 \%$ and $27.62 \%$. In figure 7 , the solid sago waste with heating pretreatment (without the addition of Trichoderma $\mathrm{sp}$ and with the addition of Trichoderma sp) resulted in crude fiber content: on the day 7 samples: $27.50 \%$ and $27.01 \%$, on the day 14 samples: $27.49 \%$ and $21.71 \%$, on the day 21 samples: $27.98 \%$ and $24.53 \%$. In figure 8 , the solid sago waste with soaking pretreatment (without the addition of Trichoderma $\mathrm{sp}$ and with the addition of Trichoderma sp) resulted in crude fiber content: on the day 7 samples: $22.03 \%$ and $21.79 \%$, on the day 14 samples: $22.62 \%$ and $17.36 \%$, on the day 21 samples: $23.00 \%$ and $19.11 \%$.

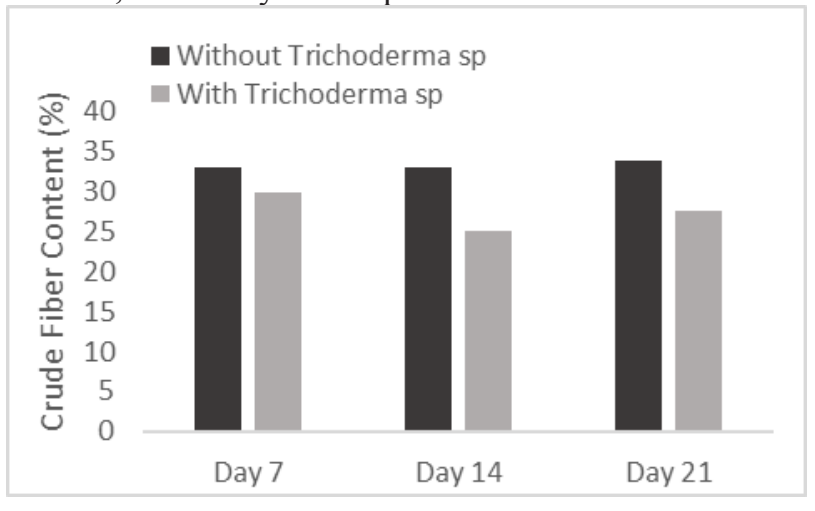

Fig. 6. Correlation of the Addition of Trichoderma sp vs Crude Fiber Content to Variables Without Pretreatment.

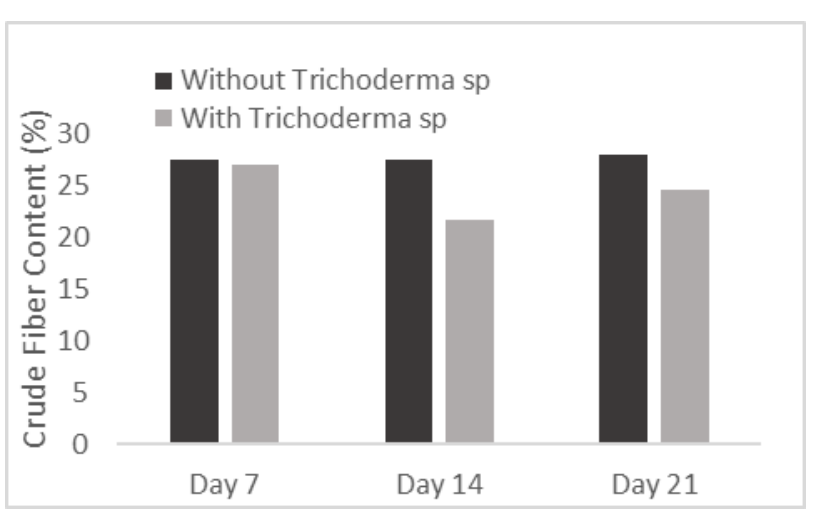

Fig. 7. Correlation of the Addition of Trichoderma sp vs Crude Fiber Content to Variables with Heating Pretreatment. 


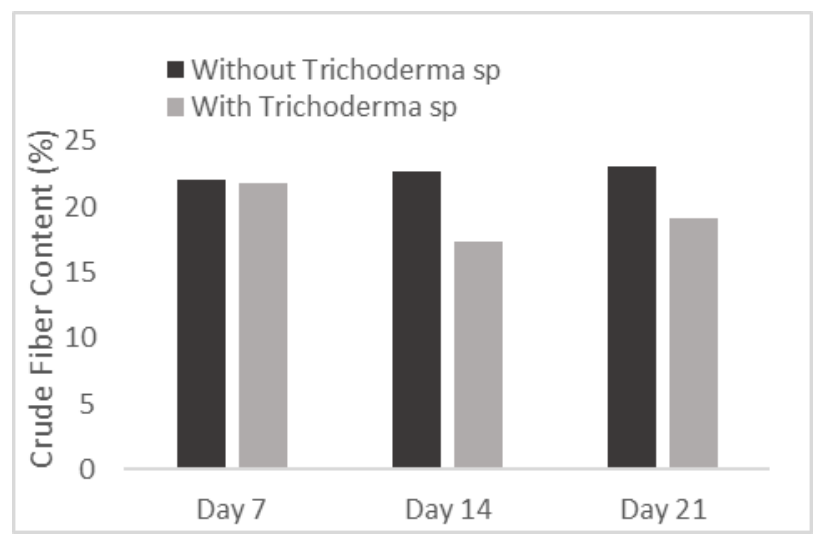

Fig. 8. Correlation of the Addition of Trichoderma sp vs Crude Fiber Content to Variables with Soaking Pretreatment.

From the figure 6,7 , and 8 , it can be seen that with the addition of Trichoderma $\mathrm{sp}$ is more effective to reduce the crude fiber content in the solid sago waste compared with without the addition of Trichoderma sp. Trichoderma $\mathrm{sp}$ is a group of complete cellulaseproducing soil fungi as well as other components required for total hydrolysis of crystalline cellulose [32]. Cellulase enzyme contains the largest components of cellobiase and $\beta$-1,4-glucan-cellobiohydrolase $(\mathrm{C} 1)$, and $\beta$-1,4-glucan-cellobiohydrolase $(\mathrm{Cx})$ in small amounts. This enzyme is hydrolytic and works either consecutively or simultaneously. Cellobiohydrolase is an enzyme that has an affinity for high level cellulose capable of breaking crystalline cellulose while endoglucanase works on amorphous cellulose. Cellobiohydrolase breaks down cellulose by cutting the hydrogen bonds that cause the glucose chains to be readily hydrolyzed. Further hydrolysis takes place to obtain selobiose and eventually glucose by $\beta$-gluconase and $\beta$-glucosidase enzymes. This series of cellulose hydrolysis reactions causes the crude fiber content of the solid sago waste to be given Trichoderma sp to be lower [33]. The factors that affecting the digestibility of feeds are contents of chemical, protein, fat presentations, fiber and minerals [27].

Figure 9, 10, and 11 shows the correlation between the effect of the addition of Trichoderma sp and the crude protein content of the solid sago waste. Figure 9 shows the correlation of the effect of the addition of Trichoderma sp vs the crude protein content on the solid sago waste variables without pretreatment. Figure 10 shows the correlation of the effect of the addition of Trichoderma $\mathrm{sp}$ vs the crude protein content on the solid sago waste variables with heating pretreatment. Figure 11 shows the correlation of the effect of the addition of Trichoderma $\mathrm{sp}$ vs the crude protein content on the solid sago waste variables with soaking pretreatment. In figure 9, the solid sago waste without pretreatment (without the addition of Trichoderma $\mathrm{sp}$ and with the addition of Trichoderma $\mathrm{sp}$ ) resulted in crude fiber content: on the day 7 samples: $3.9578 \%$ and $2.8 \%$, on the day 14 samples: $4.0439 \%$ and $4.06 \%$, on the day 21 samples: $4.0558 \%$ and $4.28 \%$. In figure 10 , the solid sago waste with heating pretreatment (without the addition of Trichoderma sp and with the addition of Trichoderma sp) resulted in crude fiber content: on the day 7 samples: $3.12 \%$ and $3.38 \%$ on the day 14 samples: $3.18 \%$ and $5.99 \%$, on the day 21 samples: $3.24 \%$ and $6.14 \%$. In figure 11 , the solid sago waste with soaking pretreatment (without the addition of Trichoderma $\mathrm{sp}$ and with the addition of Trichoderma $\mathrm{sp}$ ) resulted in crude fiber content: on the day 7 samples: $4.05 \%$ and $3.54 \%$ on the day 14 samples: $4.06 \%$ and $7.96 \%$, on the day 21 samples: $4.11 \%$ and $8.07 \%$.

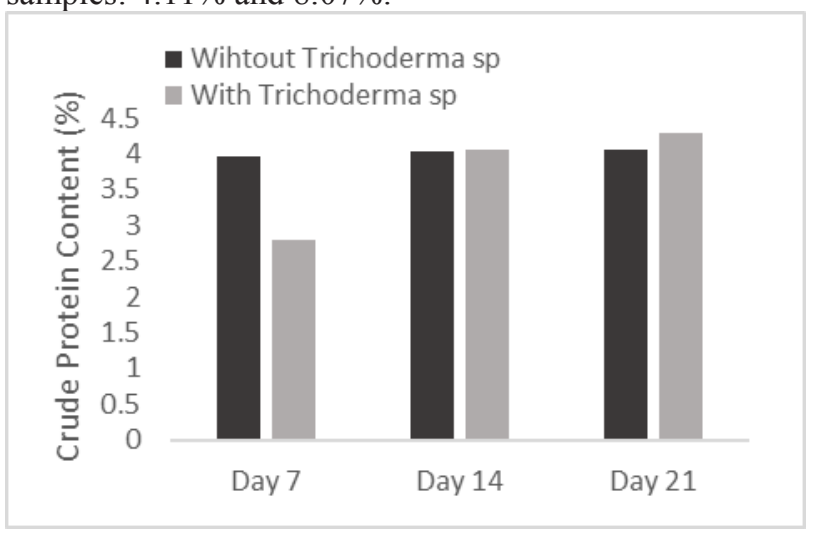

Fig. 9. Correlation of the Addition of Trichoderma sp vs Crude Protein Content to Variables Without Pretreatment.

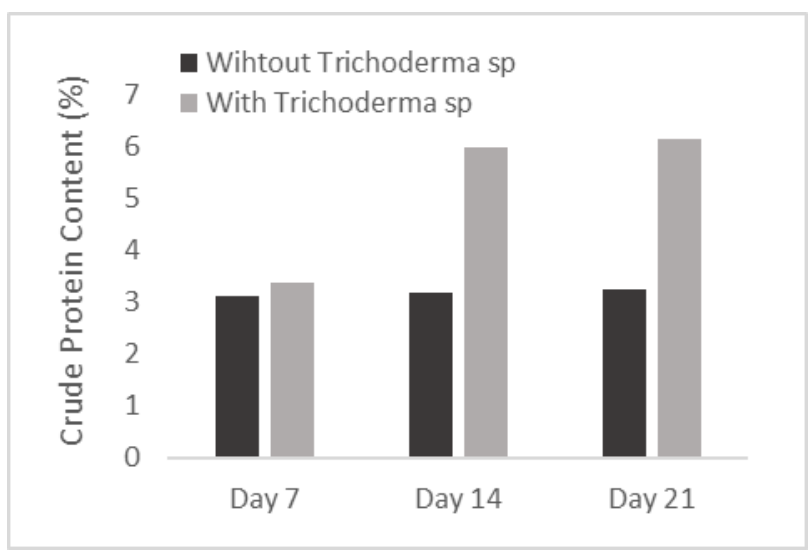

Fig. 10. Correlation of the Addition of Trichoderma sp vs Crude Protein Content to Variables with Heating Pretreatment.

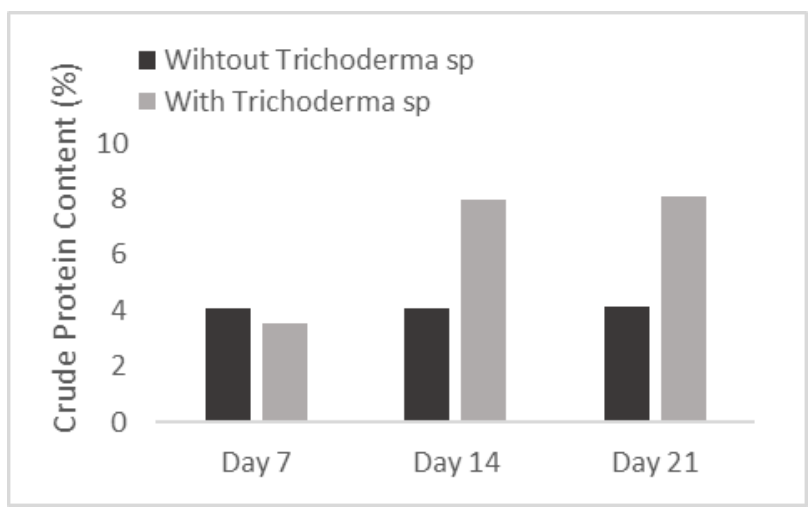

Fig. 11. Correlation of the Addition of Trichoderma sp vs Crude Protein Content to Variables with Soaking Pretreatment.

From figure 9, 10, and 11, it can be seen that with the addition of Trichoderma $\mathrm{sp}$ is more effective to raise the crude protein content in solid sago waste than with no 
addition of Trichoderma sp. The uses of microorganisms can alter the structure of components and increase enzymatic hydrolysis, added microorganisms can help cellulose hydrolysis process into glucose [34, 35]. Trichoderma $\mathrm{sp}$ is not only produces cellulose enzymes but also produces protease enzymes that serve to break down proteins [29]. The protein is converted into a polypeptide, and then becomes a simple peptide which ultimately undergoes a further reshuffle into amino acids, which will be exploited by microorganisms to multiply itself. Increasing the number of colonies of microorganisms that are single cell proteins during the fermentation process indirectly increases the crude protein content of the substrate $[27,36]$. On the variables without the addition of Trichoderma sp there was no significant change in crude protein content.

\subsection{Effect of Fermentation Time on Crude Fiber and Crude Protein Content}

Figure 12 and 13 shows the correlation of the fermentation time and the crude fiber content of solid sago waste. Figure 12 shows the correlation of fermentation time vs. the crude fiber content of the solid sago waste without the addition of Trichoderma sp while figure 13 shows the correlation of fermentation time vs. the crude fiber content of the solid sago waste with the addition of Trichoderma sp. From both figures it can be seen that on the day 7 , almost all samples except the sample without pretreatment and without the addition of Trichoderma sp had decreased contents of crude fiber from the initial level of $33.37 \%$. Then, on the day 14 all samples with the addition of Trichoderma sp continued to decrease the crude fiber content while all samples without the addition of Trichoderma sp tended not to increase or decrease the crude fiber content. On the day 21, samples with the addition of Trichoderma sp have elevated the crude fiber content while samples without the additionTrichoderma sp remain constant.

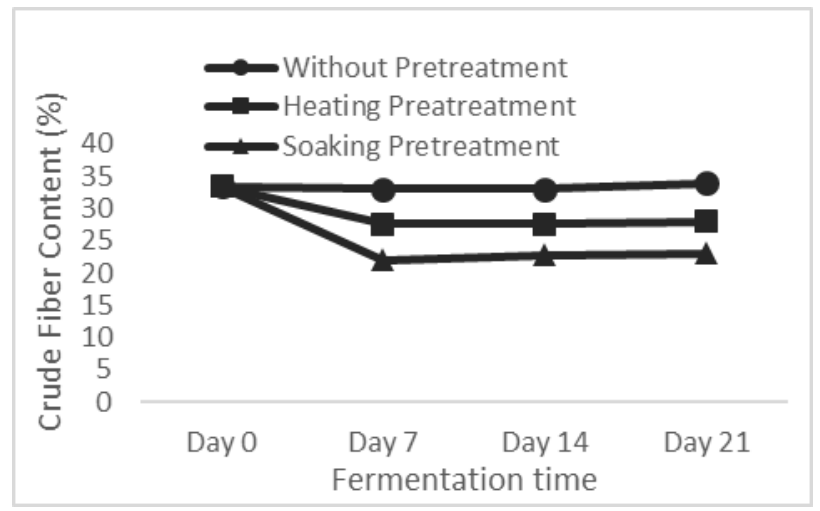

Fig. 12. Correlation of Fermentation Time sp vs Crude Fiber Content to Variables with Addition of Trichoderma sp.

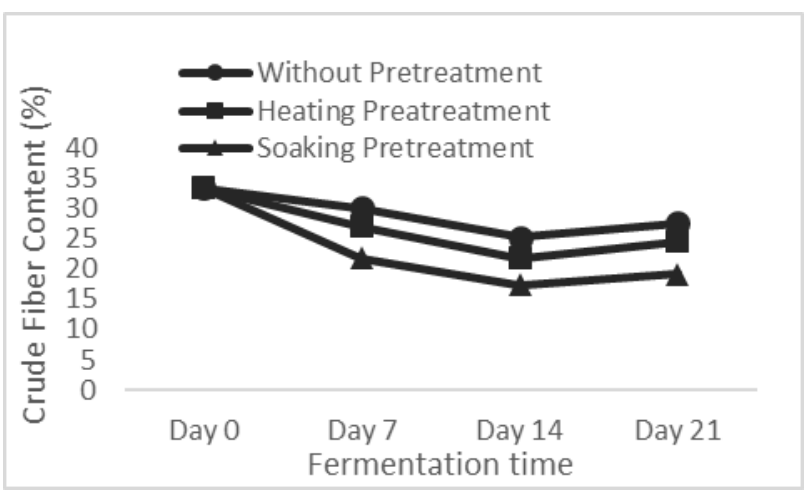

Fig. 13. Correlation of Fermentation Time sp vs Crude Fiber Content to Variables Without Addition of Trichoderma sp.

According to Saparianti [28] the longer the fermentation process takes place, then the glucose content produced from the reshuffle of cellulose is higher. This shows the longer the fermentation, cellulose hydrolytic process becomes more effective in lowering crude fiber content. This statement is reinforced by Detroy et al (1981) in [37] which explain that during the first 15 days of fermentation, cellulase-producing microorganisms can increase 2-3 times of baseline reducing sugar. The longer the fermentation means the total mold produced is also higher. Mold will multiply itself in a certain time interval so that the longer the fermentation then Trichoderma $\mathrm{sp}$ opportunity to multiply itself becomes larger so that the number of cells produced higher. The number of cellulose adsorbed by cellulase depends on the surface area and cellulase concentration. The cellulase adsorbtion on the cellulose surface is usually faster than the overall hydrolysis rate [28]. This causes the hydrolytic reaction to occur more quickly so that the crude fiber content in the solid sago waste becomes lower. This phenomenon occurred from day 0 to day 14 of fermentation on variable solid sago waste with addition of Trichoderma sp.

On the day 14 until the day 21 of fermentation there is an increase in the crude fiber content of the solid sago waste with the addition of Trichoderma sp. This is due on after the day 14 Trichoderma sp has entered the death phase. The cell wall of the dead Trichoderma $\mathrm{sp}$ is calculated as crude fiber. Meanwhile the solid sago waste variables without the addition of Trichoderma sp, the phenomenon that occurs is a decrease in crude fiber content on the day 7 except in the variable without pretreatment. There was no significant change on the day 14 and 21 compared to the previous day. This may result from the apparent delignification of the sample seen significantly on the day 7 which results in a decrease in crude fiber content. 


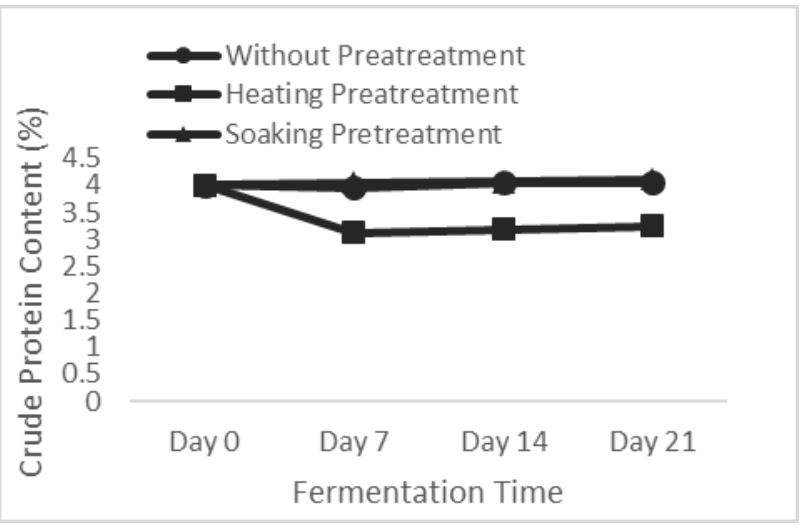

Fig. 14. Correlation of Fermentation Time sp vs Crude Protein Content to Variables with Addition of Trichoderma sp.

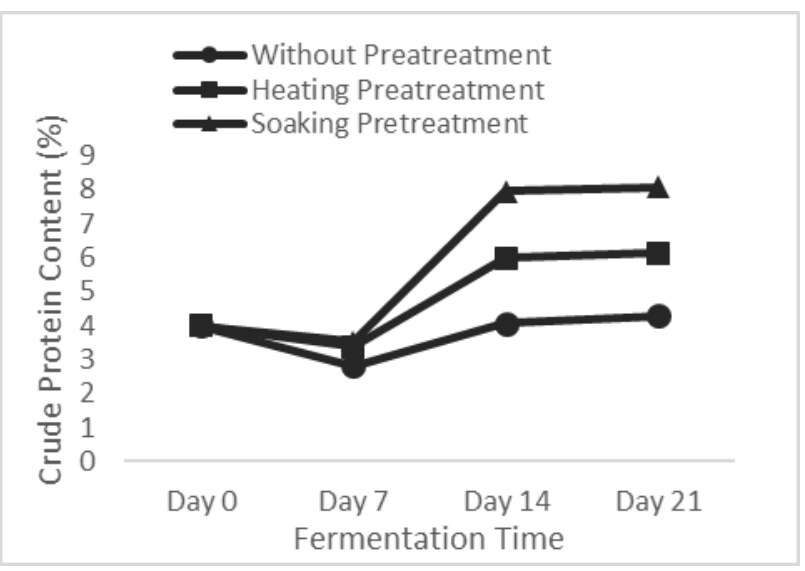

Fig. 15. Correlation of Fermentation Time sp vs Crude Protein Content to Variables Without Addition of Trichoderma sp.

Figure 14 and 15 shows the correlation of the fermentation time and the crude protein content of solid sago waste. Figure 14 shows the correlation of fermentation time vs. the crude protein content of the solid sago waste variables without the addition of Trichoderma sp, while figure. 15 show the correlation of fermentation time vs. the crude protein content of the solid sago waste variables with the addition of Trichoderma sp. From both figures it can be seen that on the day 7, all samples except the sample without pretreatment without addition of Trichoderma sp and the sample through pretreatment by soaking without Trichoderma sp had decreased crude protein content from baseline. Then, on the day 14 all samples with the addition of Trichoderma sp increased significantly in crude protein content while all samples without Trichoderma sp did not increase or decrease in crude fiber content. On the day 21, all samples either with the addition of Trichoderma sp or without the addition of Trichoderma sp did not change the crude protein content.

In the solid sago waste variables with the addition of Trichoderma sp on the day 7, the decrease is due to the protein contained in the solid sago waste consumed by Trichoderma sp for its growth. Then on the day 14, the phenomenon that occurs is the activity of formation of new proteins from Trichoderma sp through protease enzymes. According to Supriyati [17], the best fermentation length is 8-12 days where Trichoderma sp increases the crude protein content of the substrate. The protein is converted into a polypeptide, and then becomes a simple peptide which ultimately undergoes a further reshuffle into amino acids, which will be exploited by microorganisms to multiply itself. Increasing the number of colonies of microorganisms that are single cell proteins during the fermentation process indirectly increases the crude protein content of the substrate $[27,36]$.

The difference in levels of the crude protein content in sample added with Trichoderma sp was suspected because the crude fiber content of the solid sago waste had been reduced previously through the delignification process. Delignification of sago pulp aims to damage the lignin structure and swell the cellulose structure [20]. According to Saparianti [28], lignin which is a substance of lignocellulose which is a component of crude fiber will prevent enzyme penetration into substrate. The decrease in crude fiber indicates that the enzyme penetration process into the substrate is better and capable of producing higher the crude protein content.

The life phases of microorganisms in the substrate affect the content of crude fiber and crude protein [38]. The phase is generally influenced by the type of microorganisms used and the type of substrate used. The life phase of the organism is divided into 5: adaptation phase, initial growth phase, fast growth phase (logarithmic), stationary phase, and death phase. Adaptation phase is the initial period and is a phase of adjustment (adaptation), so there is no increase in the number of cells and sometimes the number of cells decreases. In the early growth phase there was no population increase. Cells undergo changes in chemical composition and increase in size and the intracellular substance increases. Logarithmic phase is a rapid multiply period. In this period can be observed features of active cells. The generation time on each microorganism can be determined in this rapid phase. At that phase it can be seen that some cells begin to divide, others half divide, and others finish splitting. In the static phase the breeding begins to decrease and some cells die. If the rate of multiply is equal to the rate of death, then the total number of cells remains constant. This may be due to reduced nutrients or the formation of metabolic products that tend to accumulate may be toxic to microorganisms. The death phase is the phase in which the multiply process has stopped. The cells are dead, which will then be followed by a lysis process. If the rate of death exceeds the rate of multiply, then the actual number of cells decreases [38].

\section{Conclusions}

Livestock feed production using solid sago waste processed through soaking pretreatment and fermentation with Trichoderma sp yields data of crude fiber content decrease from $33,3734 \%$ to $17,363 \%$ and increase of crude protein content from $4 \%$ to $7,955 \%$ at 14 days of fermentation time. This indicates the 
optimum enzyme productivity in the growth phase of Trichoderma sp in 14 days.

Authors thank to Department of Chemical Engineering, Diponegoro University for all facilities to do this research.

\section{References}

1. M. Anshar, Tadete, F.H. Elly, L.S. Kalangi, R. Hadju, District, 36, 363-371, (2016)

2. Center for Agricultural Data and Information Systems, Outlook of Agricultural Commodities Sub-Subsector of Beef Husbandry, Center for Agricultural Data and Information System of the Secretariat General of the Ministry of Agriculture, (2015)

3. M.F. Asnath, R. Priyanto, E.L. Aditia, M. Baihaqi, M. Ismail, J. Indo. Agricultural. Sci, (2015)

4. R. Salemdeeb, E.K.H.J. zu Ermgassen, M.H. Kim, A. Balmford, A. Al-Tabbaa, J. Cleaner. Production, (2016)

5. Antonius, K. Simanihuruk, J. Sirait, Use of Sago Waste as a Mixture of Complete Feed for Growth Phase Boerka Goat, National Seminar on Livestock Technology, (2013)

6. R.S. Singhal, J.F. Kennedy, S.M. Gopalakrishnan, A. Kaczmarek, C.J. Knill, P.F. Akmar, Carbohydrates Polymer 72, 1-20, Malaysia, (2008)

7. S.K. Thangavelu, A.S. Ahmed, F.N. Ani, J. App. Energy 128, 277-283, (2014)

8. Sudarsono, S. Huda, M. Yuniwati, Utilization of Palm Sugar Fiber as a Composite Material Polyester. Competitive Grant Research Report, Institute of Science \& Technology Akprindo. Yogyakarta, (2013)

9. A. Lay, Utilization of Sago Baruk as Plant Conservation of Food and Livestock Feed Products, Seminar and Exhibition of Research Results of Forestry Research Institute of Manado, (2012)

10. C. Sanchez, Biotechnology Advances 27, 185-194, (2009)

11. D. Fengel, G. Wegener, Wood: Chemistry, Ultrastructure. Reaction. Walter de Gruyter, Berlin., (1989)

12. E. Musnandar, J. Animal. Sci. 9, 225-234, (2006)

13. Budiyono, P.S. Sari, Waste Tech 30, 17-25, (2014)

14. M.J. Taherzadeh, K. Karimi, Int. J. Mol. Sci. 9, 1621-1651 (2008)

15. Z. Wang, D.R. Keshwani, A.P. Redding, J. Bioresour. Technol. 101, 3583-5, (2010)

16. S. McIntosh, T. Vancov, Bioresour. Technol 101, 6718-6727, (2010)

17. Supriyati, T. Haryati, I.G.M. Budiarsana, I.K. Sutama, LRC (2010)

18. O.A. Oseni, and M. Ekperigin, Biochemistry 19, 75-79, (2007)

19. E. Tomas-Pejo, P. Alvira, M. Ballesteros, M.J. Negro, Pretreatment Technologies for Lignocellulose-to-Bioethanol Conversion. Di dalam Pandey A (ed.), Biofuels: Alternative Feedstocks and Conversion Processes, 149-176 (2011)

20. W.L. Marsden, P.P. Dan, Gray, Cricital Rev. In Biotechnol 3, 235-576, (1986)

21. Y. Sun, Enzymatic Hidrolysis of Rye Straw and Bermudagrass for Ethanol Production, Ph.D. thesis: NC State University. Raleigh, NC, (2002)

22. P. Kumar, D.M. Barrett, M.J. Delwiche, P. Stroeve, Ind. Eng. Chem. Res. 48, 3713-3729, (2009)

23. B.E. Dale, M.J. Moreira, Biotechnology and Bioengineering Symposium 12, 31-43, (1982)

24. S. Safaria, N. Idiawati, T.A. Zaharah, Effectiveness of Cellulase Enzyme Blends from Aspergillus Niger and Trichoderma ressei in Hydrolyzing Substrates of Coconut Shell. Thesis of Faculty of MIPA University of Tanjungpura (2013)

25. V. Menon, M. Rao, Progress in Energy and Combustion Science 38, 522-550 (2012)

26. W.F. Anderson, D.E. Akin, J. Ind. Micro. Biotech, 35, 355-366 (2008)

27. Anggorodi, General Livestock Science, Jakarta: Publisher PT Gramedia (1994)

28. E. Saparianti, T. Dewanti, S.K. Dhoni, Agricultural Tech 5, 1-10, (2012)

29. Samadi, S. Wajizah, Sabda, Improving the Quality of Sugar Cane as Animal Feed Through Fermentation by Adding Different Sago Flour Levels. Banda Aceh, (2015)

30. A. Triyono, Study of the Effect of Addition of Some Acids on Protein Isolation Processes to Protein Isolate Green Bean (Phaseolus radiatus L.) Flour, Center for Appropriate Technology Development. Indo, LRC (2010)

31. M. Martawidjaja, I.K. Sutama., I.G.M. Budiarsana, T. Kostaman, Productivity of PE goat fed with fermented rice, Indo. LRC. Ciawi. Bogor (2004)

32. C.H. Prayitno, Supplementation of microminerals in Trichoderma Viride fermented agro-industry wastes reviewed from VFA and $\mathrm{N}-\mathrm{NH3}$ concentrations in vitro, Proceedings of National Seminar on Livestock and Veterinary, Bogor, 761 767, (2008)

33. P.R. Chawla, I.B. Bajaj, S.A. Survase, R. S. Singhal, Food. Tech. Biotech. 47, 107-124 (2009)

34. M. Kurakake, N. Ide, T. Komaki, Curr Microbiology 54, 424-428 (2007)

35. M. Taniguchi, H. Suzuki, D. Watanabe, K. Sakai, K. Hoshino, T. Tanaka, J. Biosci. Bioeng 100, 6737-643, (2005)

36. A.S. Agustono, Widodo, W. Paramita, J. Fish and Mar. Scie. 2, 37-43, (2010)

37. B.J.B. Wood, Microbiology of Fermented Foods. 2th. Blackie Academics and Profesional. London, (1998)

38. Wardayanti, Crude Fiber; Crude Fat and BETN Content of Corn Cocks Inoculated by Fungi Trichoderma sp at different incubation times, Faculty of Animal Husbandry, Thesis of Hasanuddin University, Makassar, (2015) 